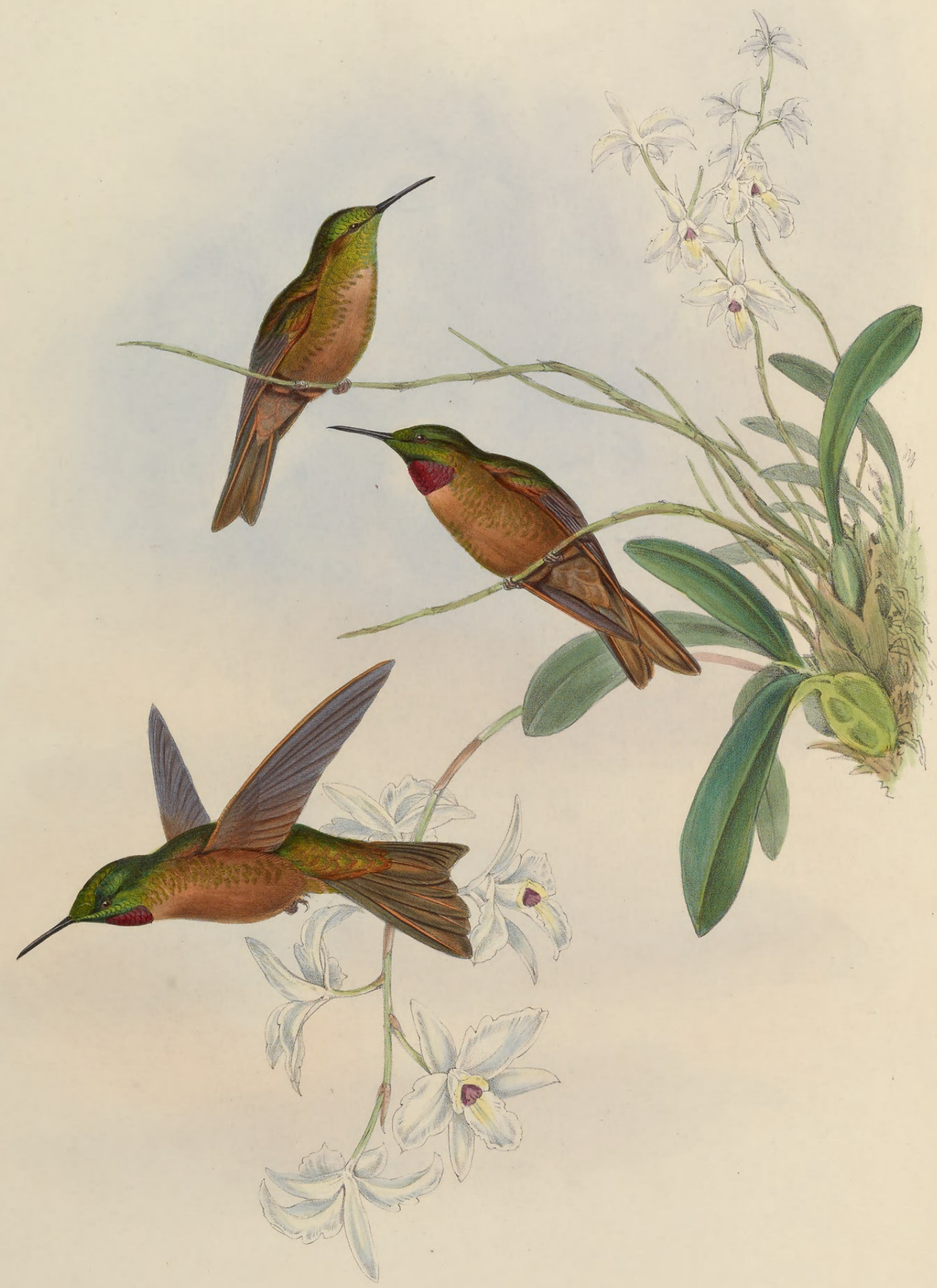




\section{PHAIOLAIMA RUBINOÏDES.}

\section{Lilac-throat.}

Trochilus rubinö̈des, Bourc. et Muls. Ann. de la Soc. Sci. de Lyon, vol. ix. 1846, p. 322. Mellisuga rubinö̈des, Gray and Mitch. Gen. of Birds, vol. i. p. 112, Mellisuga, sp. 23.

Heliomaster rubinö̈des, Bonap. Consp. Gen. Av., p. 70, Heliomaster, sp. 5.

Clytolama rubinoüdes, Bonap. Rev. et Mag. de Zool. 1854, p. 254.

Phaiolaima rubinoüdes, Reichenb. Aufz. der Colibris, p. 9.

$\mathrm{O}_{\mathrm{N}}$ a close examination I find this species differs considerably both in form and colouring from the Clytolama rubinea, with which it has hitherto been associated; I therefore adopt Dr. Reichenbach's generic appellation of Phaiolaima for this and a nearly allied species from Ecuador. These two birds are rendered very conspicuous among the Trochilidæ by the quiet and modest style of their colouring as compared with the $C$. rubinea and other allied species. The tail, as will be seen, is very peculiarly coloured, but harmonizes well both with the buff colouring of the under surface and the metallic pale-lilac-coloured throat-mark.

The Phaiolaima rubinoides is by no means a common species; and nothing, I regret to say, is known of its habits, or the localities it frequents. It is a native of New Grenada, and individuals now and then occur in collections from Bogota. The metallic throat-mark and brilliant crown are more developed in some specimens than in others, and I have seen examples where both were almost absent; the birds in this state may be females or young males of the year. Few examples in this condition have yet been sent to Europe.

Face, line down the crown, and sides of the head luminous green ; on the throat a patch of metallic lilac; sides of the head and upper surface bronzy green, the bronzy hue predominating on the wing-coverts, lower part of the back and upper tail-coverts; wings purplish brown, edged on the shoulder and outer quill with deep buff; tail pure bronze, with deep buff shafts ; under surface buff, washed with green on the flanks.

The figures are of the size of life. The plant is the Lalia acuminata. 


\section{$2 \mathrm{BHL}$ Biodiversity Heritage Library}

Gould, John. 1859. "Phæolæma rubinoïdes, Lilac-throat. [PI. 268]." $A$ monograph of the Trochilidae, or family of humming-birds 4, https://doi.org/10.5962/p.317077.

View This Item Online: https://www.biodiversitylibrary.org/item/108334

DOI: https://doi.org/10.5962/p.317077

Permalink: https://www.biodiversitylibrary.org/partpdf/317077

\section{Holding Institution}

Smithsonian Libraries

\section{Sponsored by}

Smithsonian Institution Libraries

\section{Copyright \& Reuse}

Copyright Status: NOT_IN_COPYRIGHT

This document was created from content at the Biodiversity Heritage Library, the world's largest open access digital library for biodiversity literature and archives. Visit BHL at https://www.biodiversitylibrary.org. 